\title{
Research on Improving the Salary System of the People's Police in China
}

\author{
Shumian $\mathrm{He}$ \\ Chinese People's Armed Police Force Academy, Langfang 065000, China \\ He_sm@126.com
}

Keywords: improvement, the people's police, salary system.

\begin{abstract}
At present, the salary system of the People's police is not adapted to the social requirement. There are some problems, such as lack of pertinence, unreasonable structure, low overall level, and the difficulty to implement economic compensation for work on vacations, etc. So we should reform and improve the salary system from salary structure, fiscal guarantee and growth mechanism to effectively protect the rights of the people's police.
\end{abstract}

\section{The Problem of the Current Police Salary System in Our Country}

\subsection{The Police Salary System Based on the Salary System of the Civil Servant Can Not Reflect the Characteristics of the Police Work.}

The People's Police Law of the People's Republic of China was issued in 1995 and revised in 2012. The fortieth article stipulates that the people's police should enjoy the national civil servant salary system and enjoy the title allowances and other allowances, subsidies and insurance benefits. Therefore, the current police's salary system is the same as the China's civil servant salary system and both structures are roughly the same which includes basic payment, allowances, subsidies and bonuses. The basic payment is composed of two parts, duty allowances and rank allowances. The allowances and subsidies mainly refer to working allowance, living allowance, police-rank allowances, housing subsidies and medical subsidies. The bonus is a one-time bonus at a year's end given on the annual appraisal in job qualifications. But compared to the work of general civil servants, the police work is characterized of great intensity, high risk and poor working environment. The general civil servant salary system does not reflect the principle of distribution according to different work, so it damages the police benefits. Therefore, the police title allowances has been increased based on the civil servant salary system, which reflects the characteristics of the police work. But the increased police title allowances in the total salary is in the low proportion (generally below 16\%), which doesn't reflect fully that some police work is harder than the civil servants. At the same time, it is not conducive to enhance the sense of honor and pride and will have a bad impact on the cohesion and fighting capacity of the police force.

\subsection{The Police Salary System Based on the Local Financial Support Has Caused a Huge Difference in all Parts of the Country.}

The police salary in China is guaranteed by the local finance, but the imbalance in the development of the local governments has resulted in a great difference in the local fiscal revenue and expenditure. It is mainly manifested in two aspects: the first is the difference in the composition of salary is very big. For example, there are more than 10 police salary items in some southern provinces, but only 5 in some provinces and cities in the north. The second is the great differences in the amount of the items. For example, the work allowance is only 800 or 900 yuan in some northern provinces and it is above 3000 yuan in some southern provinces. Even in the same province, there will be a different income gap in the city and county. Take Hebei province for instance, with the same duty and the same rank, the allowance in Shijiazhuang is more than 1000 yuan higher than Langfang. From a general perspective, the police income in developed areas is basically higher than that that in underdeveloped areas. The income of police in provincial capital cities is higher than that of the police in cities and counties. 


\subsection{The Same Amounts of Police Salary in the Same Area Doesn't Reflect the Different Intensity of the Different Kinds of Police Work.}

The police is obviously a whole concept, but specifically speaking, the police work is various. There are different categories, such as the traffic police, residential registration police, public security police and criminal police and so on. Because of the different requirements of work, there are great differences in the content of the work, work time and work intensity in the whole police system. The individual duty is not all the same, take residential registration police and criminal police for example, the degree of risk of their work is different, but in the salary structure, there is little difference. Therefore, it can be said that there is some unfairness in the current salary system.

\subsection{The Overall Level of Police Salary Is Low, Which May Affect the Stability and Sustainable Development of the Police Force.}

There is no doubt that the police is a high-risk occupation. There are 438 police officers and active duty officers and soldiers who sacrifice their lives and 4599 police officers and service men wounded in 2015. There are 362 policemen died and 4913 policemen injured. In general, risk and benefit should be proportional, which means that the job with higher risks should be paid more. But in China, the salary level of people's police is only slightly higher than the average level of society and it can not match the police contributions. The normal basic relationship between income and risk is not shown exactly.

The main sources of police personnel system are from social forces and demobilized cadres. On the current situation, because of the military the adjustment of salary system and the changes of resettlement policy, the retirement tendency will be inclined to choose independent careers. Access to the police system is no longer their first choice. Therefore, social recruitment is the main source of the people's police which needs to compete against other units for talents in society. In the process of competition, if the salary level is lower than the average level of the society, the job will not be attractive, and it will inevitably lead to difficulties in recruitment and cannot absorb the talented people in society. At the same time, high salaries outside the police force may also cause the talent loss, which affects the cohesiveness and fighting capacity of the police force.

\section{An Analysis on the Necessity of Improving the Police Salary System in China}

\subsection{The Principle of Distribution According to Work Requires Improvement of the Current Police Salary System.}

Distribution according to work is the basic principle in the field of income distribution. But in view of the current salary system and income level of the police in our country, this principle is not observed completely. First of all, the working time of our police is much longer than 40 hours per week. Overtime work has become a common practice for policemen. Police work is vividly described as "5+2" and "white plus black". According to incomplete statistics, the average weekly overwork time police at basic level is more than 20 hours, and that for criminal police brigade is up to 50 hours. Suppose we work overtime for 20 hours per week, we will need to overwork more than 130 working hours per year. Secondly, the overwork time of the police has not been properly compensated. According to the forty-fourth article of the Labor Law of the People's Republic of China, under one of the following circumstances, the employer should give the standard pay and workers should be paid more than the normal working hours payment: (i) for working, no payment should be lower than $150 \%$ of the normal payment; (ii)For the workers who have been arranged work on the rest day, no payment should be lower than $200 \%$ of the normal payment; (iii) for working in legal holidays, the payment should not be less than $300 \%$ of the normal payment. But in 2009, Ministry of Human Resources and Social Security and Ministry of Finance jointly issued the overtime work subsidy notice for people's police working on rest days, which stipulates the standard of subsidies for overtime work of police. It says except the legal working days, subsidy for one day-work on rest day is 80 yuan, subsidy for one-day work in legal holidays is 100 yuan. This regulation apparently makes police salary greatly diminished. If calculated according to the national urban non-private sector employment in 
2016, the average annual salary of 67569 yuan, and the daily average payment is about 270 yuan based on 250 working days of the year, so the current standard is only equivalent to the $30 \%$ of the national average standard. At the same time, the required funds are adjusted by the local governments according to the actual economic conditions, and the overtime work compensation for the police in underdeveloped areas is again discounted.

\subsection{The Principle of Human Resource Allocation Under the Condition of Market Economy} Requires the Improvement of the Current Police Salary System.

Since the reform and opening up, China's market economy has been gradually improved and the role that the market is playing in the allocation of production factors is more important and widespread and the most dynamic elements of human resources have received wide attention. Market becomes the most important factor for the flow and allocation of human resources. The police as the convoy of market is also an important part and must be respected and the salary system should comply with the market laws. Only in this way can the salary system fully reflect the value of the police occupation in the market economy. Otherwise it will lead to a substantial loss of talents and the team of the police will lose its stability.

\section{Ways to Improve the Police Salary System of Our Country}

\subsection{Canceling Title Allowances While Adding Title Payment.}

In general, police titles are the prominent symbol of people's police compared with the civil servants, which is a reflection of the personal ability and contribution to the police work. It enhances the sense of honor and pride of the police. Therefore, the title allowances can be canceled, the title payment will be reset and incorporated into the police basic payment as a part of basic salary, which is composed of duty payment, title payment and the title payment. The proportion of title payment should be increased in the basic salary. From the current standards, title allowances have accounted for only $27 \%$ or so (the rank payment accounted for about $48 \%$, duty payment for about $25 \%$ ) of the total sum of duty payment, rank payment and title allowance. So the proportion of title payment should be greatly increased in the basic salary and it should gradually be the major part of the basic salary and make a good preparation for the future police salary system.

\subsection{Adjusting the Channel of Funds Guarantee and Avoiding the Different Payment for the Same Work.}

At present, local police salary is supported by local fiscal, because the local financial status is quite different, the police salary is accordingly different. Therefore, the police salary should be guaranteed directly by central government in order to solve the imbalance in police salary system so that with the same rank, the police will roughly get the same salary. What's more, it can reduce the burden of the local fiscal, especially those underdeveloped areas to a certain extent. At the same time, in order to reflect the main responsibility of the local governments, the central government fiscal should guarantee the police salary while the governments of different levels should be responsible for police equipment construction so that under the premise of ensuring the basic needs, the level of police training and combat capability can be gradually strengthened and the equipment construction can be developed reasonable and orderly in accordance with the local economic development and stability.

\subsection{Improving the Police Allowances and Subsidy System According to the Police Occupation and Different Areas.}

On the basis of central fiscal guarantee and equal pay for equal work, a complete system of regional allowance and subsidy related to different areas can be established in order to achieve the incentive mechanism and the fair distribution principle according to different work. Therefore, we should design and improve the allowance and subsidy system in three dimensions. Firstly, a police subsidy system based on the different kinds of police should be set up; secondly, the different duty allowances and subsidy system based on the duty difference should be established and the basic work and basic positions should be given more payment; thirdly, the allowances and subsidy system based on the different regions should be established. 


\subsection{Perfecting the Police Salary Growth Mechanism.}

Every policeman from the team is necessary for the combating capacity. There is a competition between the police system and social enterprises for talents. So along with the increase of salary in society, the police salary should also be increased in order to share the social achievement and economic fruits and make the police work attractive to absorb and retain the talents, optimize the police force structure and constantly improve the combating capacity of the police force. Therefore, to establish the long-term growth mechanism of police salary, military salary system and foreign police salary system can be used as a reference. A growth mechanism of regular increase periodically and salary increase for promotion and the growth mechanism of overall salary increase in accordance with price index increase should be established, and at the same time, the salary of local units should be considered in order to guarantee the police salary increase in accordance with the economic and social development and realize preferential treatment for the police.

\subsection{Perfecting the System of Economic Compensation for Work Overtime and on Legal Vacations.}

The current economic compensation for overtime work and work on vacation are not only low but also contrary to the relevant laws. Therefore, we should strive to reduce overwork time and encourage the police to take a vacation on the basis of clarifying the police duties and increasing staff appropriately. At the same time, we should improve the economic compensation system of work overtime and on vacations for the police and set the compensation amount according to the compensation standard stipulated by law and the income level of urban non-private units in the previous year and timely give it to the policemen concerned to protect their legitimate economic rights and interests.

\section{References}

[1]. Information on: http://www.npc.gov.cn/wxzl/gongbao/2013-02/25/content_1790862.htm.

[2]. Information on: http://news.cpd.com.cn/n3559/c31833836/content.html.

[3]. Information on: http://news.xinhuanet.com/legal/2017-03/07/c_129503653.htm.

[4]. Information on: http://news.163.com/06/0223/10/2AKV9EN60001124T.html

[5]. Information on: http://www.gov.cn/banshi/2005-05/25/content_905.htm.

[6]. Information on: http://www.moj.gov.cn/index/content/2010-01/20/content_6357476.htm.

[7]. Information on: http://www.gov.cn/zhengce/2017-05/27/content_5197573.htm. 